\title{
First record of the genus Baris Germar, 1817 (Coleoptera: Curculionidae), in Dominican amber
}

\author{
G. Poinar Jr. ${ }^{1}$ and A. A. Legalov ${ }^{2}$ \\ ${ }^{1}$ Department of Integrative Biology, Oregon State University, Corvallis, OR 97331, USA \\ ${ }^{2}$ Institute of Systematics and Ecology of Animals, Siberian Branch, Russian Academy of Sciences, Frunze Street, 11, \\ Novosibirsk 630091, Russia \\ Correspondence to: G. Poinar Jr. (poinarg@science.oregonstate.edu)
}

Received: 6 August 2014 - Revised: 5 September 2014 - Accepted: 12 September 2014 - Published: 20 October 2014

\begin{abstract}
A new weevil species - Baris grossacavis Poinar and Legalov, sp. nov. (Coleoptera: Curculionidae) - is described from Dominican amber. The new species is close to Baris rubripes Casey, 1892, but differs by possessing large punctures over much of its body, including the pronotum; elytral intervals with rows of narrow scales, and narrow elytral intervals.

The fossil is the first record of the subfamily Baridinae from any amber source and the first record from the Miocene.
\end{abstract}

\section{Introduction}

Beetles of the subfamily Baridinae from the family Curculionidae are a monophyletic group, sometimes considered as a separate family (Zherikhin and Gratshev, 1995). The systematics of this group are rather complicated (AlonsoZarazaga and Lyal, 1999; Morimoto and Yoshihara, 1996), but the morphology is well known (Davis, 2009). The Baridinae are widely distributed throughout the world, especially in the New World (O'Brien and Wibmer, 1982; Wibmer and O'Brien, 1986). The early discoveries of the superfamily Curculionoidea were from the Middle-Upper Jurassic (Arnoldi, 1977; Gratshev and Legalov, 2011; Legalov, 2011, 2012, 2013b). The oldest record of the family Curculionidae was in the Aptian of Mongolia (Legalov, 2012, 2014).

Recent studies have shown that the Dominican amber weevil fauna is quite extensive (Davis and Engel, 2006a, b, c, 2007, 2009; Poinar, 2009; Poinar and Brown, 2011; Poinar et al., 2013; Poinar and Legalov, 2014a, b, c, d, e, f); however no members of the subfamily Baridinae had previously been recovered from this fossil source.
The present study describes the first representative of the subfamily Baridinae from Dominican amber.

\section{Material and methods}

The specimen was obtained from an amber mine in the Cordillera Septentrional of the Dominican Republic. Dating of Dominican amber is controversial, with the latest purported age of 20-15 Mya based on Foraminifera (IturraldeVinent and MacPhee, 1996) and the earliest of 45-30 Mya based on coccoliths (Schlee, 1990). In addition, Dominican amber is secondarily deposited in sedimentary rocks, which makes a definite age determination difficult (Poinar and Mastalerz, 2000). A range of ages for Dominican amber is possible as the amber is associated with turbiditic sandstones of the Upper Eocene to Lower Miocene Mamey Group (Draper et al., 1994). Dominican amber was produced by the leguminous tree Hymenaea protera Poinar (Poinar, 1991), and a reconstruction of the Dominican amber forest based on amber fossils indicated that the environment was similar to that of a present-day tropical moist forest (Poinar and Poinar, 1999).

\section{Systematic paleontology}

Family: Curculionidae Schoenherr, 1825

Subfamily: Baridinae Schoenherr, 1836

Tribe: Baridini Schoenherr, 1836

Genus: Baris Germar, 1817 


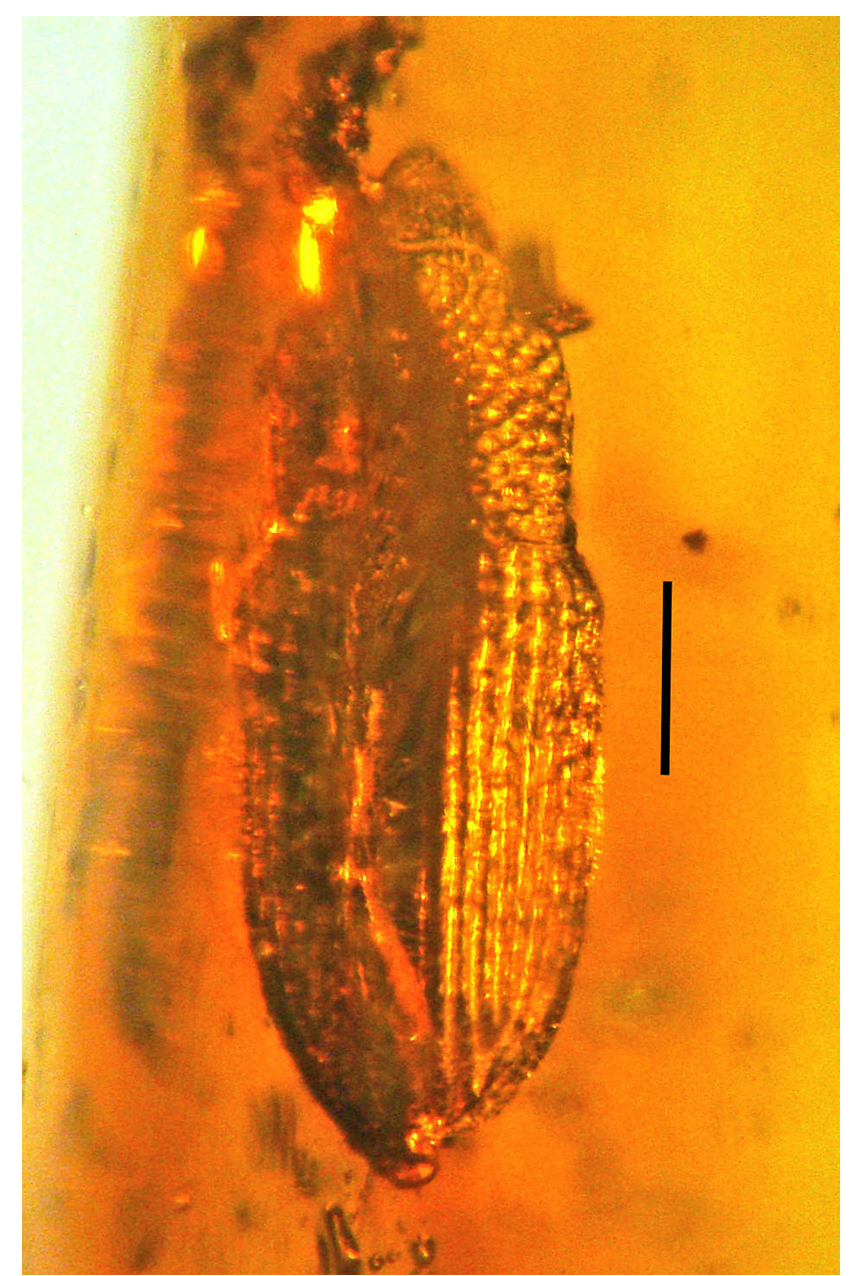

Figure 1. Dorsal view of Baris grossacavis sp. nov. Scale bar: $0.44 \mathrm{~mm}$.

\section{Baris grossacavis sp. nov.}

Etymology. The specific epithet is derived from the Latin grossus (large or coarse) and the Latin cavus (hole or hollow), in reference to the large punctures over the body.

Holotype. Female, deposited in the Poinar amber collection (accession \# C-155) maintained at Oregon State University, Corvallis, Oregon.

Type locality. Amber mine in the northern portion of the Dominican Republic.

Diagnosis. The new species is close to Baris rubripes Casey, 1892, but differs by possessing larger punctures over the body, some of which occur in coarse short, longitudinal grooves, elytral intervals with rows of narrow scales, and narrower elytral intervals.

Remarks. The strongly ascending mesepimeron, tibiae with large uncus, and eyes widely separated dorsally suggest placement in the subfamily Baridinae. Placement of this species in the tribe Baridini is based on the tarsus, with claws separate at the base and the pygidium exposed beyond the

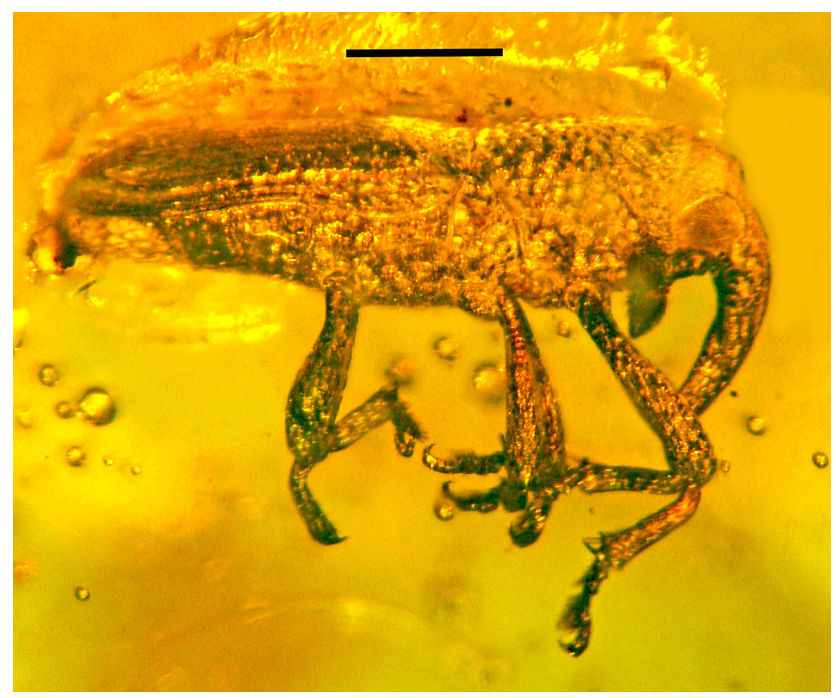

Figure 2. Lateral view (right) of Baris grossacavis sp. nov. Scale bar: $0.47 \mathrm{~mm}$.

elytra. The new species is placed in the genus Baris based on the narrowly separated front coxae, the prosternum having a slight median longitudinal impression, the rostrum being distinctly separated from the head by a transverse impression, and the body vestiture lacking dense scales and a metallic luster.

Description. Size: length of body (without rostrum), $2.2 \mathrm{~mm}$; length of rostrum, $0.5 \mathrm{~mm}$. Body black, without dense scales and metallic luster.

Head: rostrum quite short, 0.7 times as long as pronotum, 6.0 times longer than wide at apex, 4.2 times longer than wide in middle, 3.2 times longer than wide at base, weakly curved, with coarse transversally rugose punctures, distinctly separated from head by transverse impression; antennal scrobes lateral and directed toward ventral margin of eye; forehead quite wide, flattened, punctured; eyes large, rounded, not protruding from the head contour, widely separated dorsally, with transverse diameter equal to rostrum base width; vertex weakly flattened, coarsely punctured; temples very short; antennae inserted in middle of rostrum, quite wide, almost reaching middle of pronotum; scape elongated, 6.6 times longer than wide; funicle with first to seventh antennomeres quite wide and conical; club compact, 1.7 times longer than wide, barely shorter than funicle.

Pronotum: bell-shaped; 1.4 times longer than wide at apex, 1.0 times longer than wide in middle and at base; disk weakly flattened, weakly narrowed at apex, densely and coarsely punctured; distance between points less than diameter of points; sides with coarse, longitudinal rugose punctures; scutellum trapezoidal, flattened.

Elytra: elongated and weakly convex, 1.7 times longer than width at base and in middle, 3.0 times longer than width at apical fourth, 2.0 times as long as pronotum; greatest width in middle, elytral base 1.2 times as wide as pronotum base 


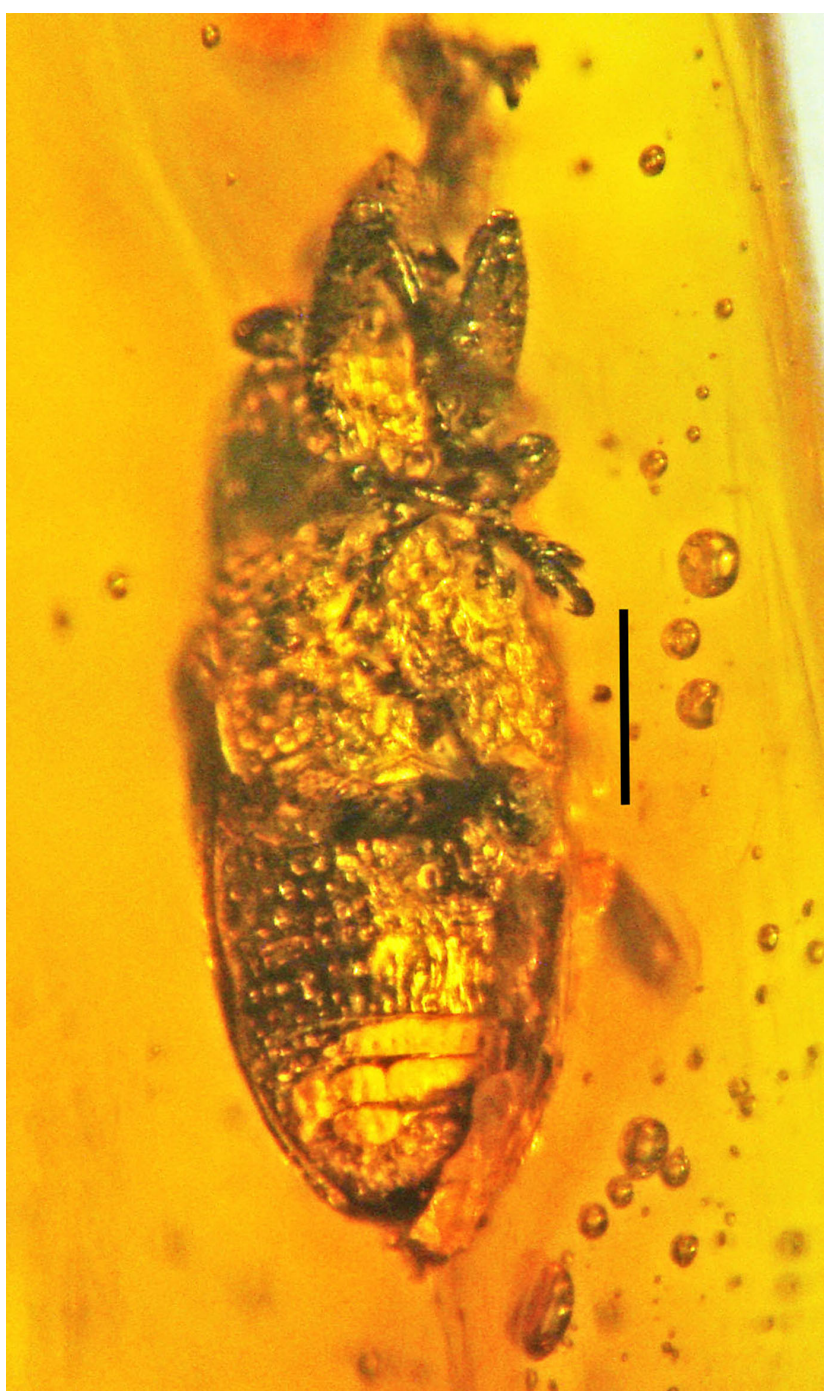

Figure 3. Ventral view of Baris grossacavis sp. nov. Scale bar: $0.44 \mathrm{~mm}$.

width; humeri weakly convex; striae regular, deep; intervals flattened, quite narrow, 1.5 times as wide as striae, with row of points and adjacent scales; apex of elytra rounded.

Thorax: coarsely punctured; prosternum with slight median longitudinal impression; postocular lobes absent; precoxal portion of prosternum elongated, 2.5 times as long as procoxa length; procoxal cavities separated; postcoxal portion of prosternum short, 1.2 times as long as procoxa length; middle coxal cavities quite widely separated; mesepimeron strongly ascending; metathorax 2.0 times as long as metacoxa length; metepisternum quite narrow, 4.6 times longer than wide in middle.

Abdomen: weakly convex ventrally, coarsely punctured, distance between points approximately equal to diameter of points; first and second ventrites elongated, almost equal in length; first ventrite 1.7 times as long as metacoxa length; second ventrite 0.9 times as long as first ventrite; third and

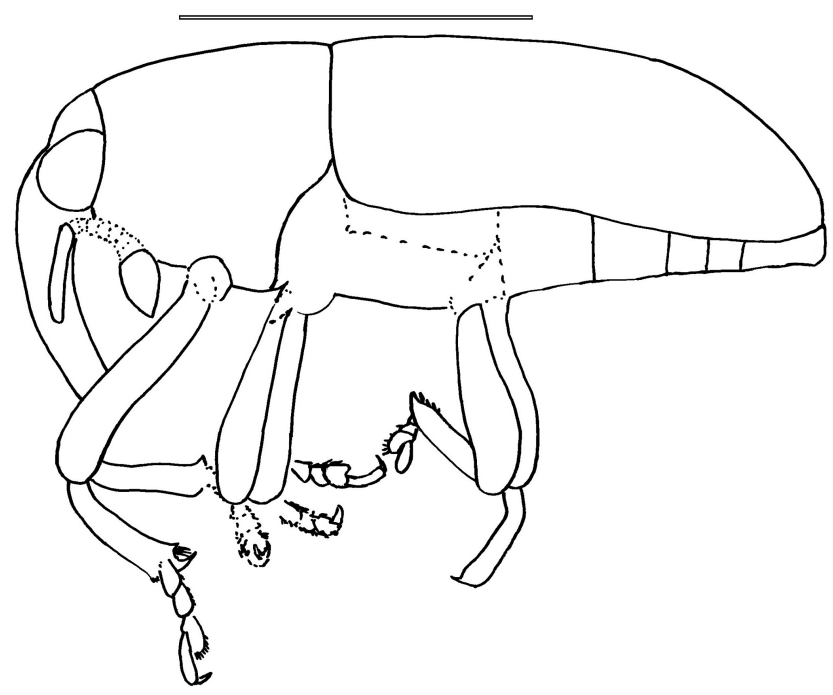

Figure 4. Lateral view (left) of Baris grossacavis sp. nov. Scale bar: $1.0 \mathrm{~mm}$.

fourth ventrites short, equal in length; third ventrite 0.5 times as long as second ventrite; fifth ventrite elongated, 2.2 times as long as fourth ventrite. Pygidium exposed beyond elytra.

Legs: legs long; front and middle coxae spherical; hind coxae transverse; femora weakly clavate, without teeth; trochanters obconical; profemora 5.2 times longer than wide in middle; mesofemora 4.4 times longer than wide; metafemora 3.7 times longer than wide; tibiae slightly curved, with uncus, mucro and two groups of setae; protibiae 4.8 times longer than wide in middle; metatibiae 4.6 times longer than wide in middle; tarsi long; first to third tarsomeres conical; fifth elongated; tarsomeres with pulvilli on underside; claws free, large, without tooth.

\section{Discussion}

The first description of a fossil of the subfamily Baridinae was Centrinus longipes Piton, 1940, from the Paleogene of France (Piton, 1940). The oldest American Baridinae, which includes four described species, probably of the genera Aulobaris LeConte, 1876 (Baridini), and Centrinus Schoenherr, 1825 (Apostasimerini), were from the middle Eocene Green River Formation (Scudder, 1893). Undescribed males with prosternal horns were also recorded from the Green River deposits (Davis and Engel, 2010). The rich fauna (20 species) comprising the genera Aulobaris, Baris, Centrinus, and Pachybaris LeConte, 1876, and the two fossil genera Miogeraeus Wickham, 1916, and Catobaris Scudder, 1893, of the tribes Apostasimerini and Baridini were described from the upper Eocene-Oligocene Florissant shales (Scudder, 1893; Wickham, 1912a, b, 1916, 1917). One species, Baris naviculare (Foerster, 1891), was described from the middle Oligocene of France (Foerster, 
1891). Representatives of the subfamily Baridinae are not known from Eocene Baltic amber (Alekseev, 2013; Hieke and Pietrzeniuk, 1984; Legalov, 2013a). Baris grossacavis is first record of the subfamily Baridinae from any amber source and the first record from the Miocene.

Acknowledgements. This study was partially supported by the Russian Foundation for Basic Research (grant number 12-04-00663-a).

Edited by: D. Korn

Reviewed by: A. Bukejs and L. Gultekin

\section{References}

Alekseev, V. I.: The beetles (Insecta: Coleoptera) of Baltic amber: the checklist of described species and preliminary analysis of biodiversity, Zool. Ecol., 23, 5-12, doi:10.1080/21658005.2013.769717, 2013.

Alonso-Zarazaga, M. A. and Lyal, C. H. C.: A world catalogue of families and genera of Curculionoidea (Insecta: Coleoptera), Entomopraxis: Barcelona, Spain, 1999.

Arnoldi, L. V.: Rhynchophora. Family Eobelidae, Mesozoic Coleoptera, Proc. Palaeontol. Inst., 161, 142-144, 1977.

Davis, S. R.: Morphology of Baridinae and related groups (Coleoptera, Curculionidae), ZooKeys, 10, 1-136, doi:10.3897/zookeys.10.47, 2009.

Davis, S. R. and Engel, M. S.: A zygopine weevil in Early Miocene amber from the Dominican Republic (Coleoptera: Curculionidae), Caribbean J. Sci., 42, 255-257, 2006a.

Davis, S. R. and Engel, M. S.: A weevil of the genus Caulophilus in Dominican amber (Coleoptera: Curculionidae), Polskie Pismo Entomol., 75, 101-104, 2006b.

Davis, S. R. and Engel, M. S.: Dryophthorine weevils in Dominican amber (Coleoptera: Curculionidae), Trans. Kans. Acad. Sci., 109, 191-198, 2006c.

Davis, S. R. and Engel, M. S.: Cossonine weevils in Dominican amber (Coleoptera: Curculionidae), Linzer Biol. Beitr., 39, 803820, 2007.

Davis, S. R. and Engel, M. S.: An orthognathine weevil of the genus Mesocordylus in Dominican amber, Beitr. Entomol., 59, 233238, 2009.

Davis, S. R. and Engel, M. S.: Antiquity and evolution of prosternal horns in baridine weevils (Coleoptera: Curculionidae), J. Paleontol., 84, 916-924, doi:10.1666/09-160.1, 2010.

Draper, G., Mann, P., and Lewis, J. F.: Hispaniola, 129-150, in: Caribbean Geology: An introduction, edited by: Donovan, S. and Jackson, T. A., University West Indies Publishers' Association, Kingston, Jamaica, 1994.

Foerster, B.: Die Insekten des "Plattigen Steinmergels" von Brunstatt, Abh. Geol. Specialkarte Elsass-Lotheringen, 3, 333-594, 1891.

Gratshev, V. G. and Legalov, A. A.: New Mesozoic Ithyceridae Beetles (Coleoptera), Paleontol. J., 45, 76-81, doi:10.1134/S0031030111010060, 2011.

Hieke, F. and Pietrzeniuk, E.: Die Bernstein-Käfer des Museums für Naturkunde, Berlin (Insecta, Coleoptera), Mitt. Zool. Museum Berlin, 60, 297-326, 1984.
Iturralde-Vinent, M. A. and MacPhee, R. D. E.: Age and Paleogeographic origin of Dominican amber, Science, 273, 1850-1852, 1996.

Legalov, A. A.: First record of Anthribid beetles from the Jurassic of Kazakhstan (Coleoptera: Anthribidae), Paleontol. J., 45, 629633, doi:10.1134/S0031030111060074, 2011.

Legalov, A. A.: Fossil history of Mesozoic weevils (Coleoptera: Curculionoidea), Insect Sci., 19, 683-698, doi:10.1111/j.17447917.2012.01508.x, 2012.

Legalov, A. A.: New and little known weevils (Coleoptera: Curculionoidea) from the Paleogene and Neogene, Historical Biology, 25, 59-80, doi:10.1080/08912963.2012.692681, 2013a.

Legalov, A. A.: Review of the family Anthribidae (Coleoptera) from the Jurassic of Karatau: subfamily Protoscelinae, Genus Protoscelis Medvedev, Paleontol. J., 47, 292-302, doi:10.1134/S0031030113030064, 2013b.

Legalov, A. A.: The oldest Brentidae and Curculionidae (Coleoptera: Curculionoidea) from the Aptian of Bon-Tsagaan, Historical Biology, 26, 6-15, doi:10.1080/08912963.2012.751103, 2014.

Morimoto, K. and Yoshihara, K.: On the genera of the Oriental Baridinae (Coleoptera: Curculionidae), Esakia, 36, 1-59, 1996.

O'Brien, C. W. and Wibmer, G. J.: Annotated checklist of the weevils (Curculionidae sensu lato) of North America, Central America, and the West Indies (Coleoptera: Curculionoidea), Mem. Amer. Entomol. Inst., 34, 1-382, 1982.

Piton, L.: Paléontologie du gisement Éocène de Menat (Puy-deDôme) (Flore et faune), Clermont-Ferrand: Imprimeries Paul Vallier, 1940.

Poinar Jr., G. O.: Hymenaea protera sp.n. (Leguminosae: Caesalpinoideae) from Dominican amber has African affinities, Experientia, 47, 1075-1082, 1991.

Poinar Jr., G. O.: Dominibrentus leptus, n. gen., n. sp. (Curculionoidea, Brentidae, Cyphagoginae, Dominibrentini, n. tribe), a straight snouted weevil in Dominican amber, Historical Biology, 21, 51-55, doi:10.1080/08912960903122807, 2009.

Poinar Jr., G. O. and Brown, A. E.: Descriptions of a broad-nosed weevil (Eudiagogini: Curculionidae) and false ladybird beetle (Nilionini: Nilionidae) in Dominican amber, Historical Biology, 23, 231-235, doi:10.1080/08912963.2010.527159, 2011.

Poinar Jr., G. and Legalov, A. A.: Bicalcasura maculata n. gen., n. sp. (Curculionoidea: Dryopthtoridae) with a list of weevils described from Dominican amber, Historical Biology, 26, 449-453, doi:10.1080/08912963.2013.786066, 2014a.

Poinar Jr., G. and Legalov, A. A.: New Cryptorhynchinae (Coleoptera: Curculionidae) in Dominican amber, Historical Biology, 26, 502-534, doi:10.1080/08912963.2013.797971, 2014b.

Poinar Jr., G. and Legalov, A. A.: New species of the subfamily Conoderinae (Coleoptera: Curculionidae) in Dominican amber, Historical Biology, 26, 556-562, doi:10.1080/08912963.2013.802311, 2014c.

Poinar Jr., G. and Legalov, A. A.: Pleurambus strongylus n. gen., n. sp. (Coleoptera: Belidae) in Dominican amber, Historical Biology, 26, 670-674, doi:10.1080/08912963.2013.829825, 2014d.

Poinar Jr., G. and Legalov, A. A.: New Apioninae (Coleoptera: Brentidae) in Dominican amber, Historical Biology, doi:10.1080/08912963.2013.871010, 2014e. 
Poinar Jr., G. and Legalov, A. A.: New species of the subfamily Cossoninae (Coleoptera: Curculionidae) in Dominican amber, Historical Biology, doi:10.1080/08912963.2014.888422, $2014 \mathrm{f}$.

Poinar Jr., G. O. and Mastalerz, M.: Taphonomy of fossilized resins: determining the biostratinomy of amber, Acta Geol. Hisp., 35, 171-182, 2000.

Poinar Jr., G. O. and Poinar, R.: The Amber forest. Princeton, NJ: Princeton University Press, 1999.

Poinar Jr., G., Legalov, A. A., and Brown, A. E.: Brachycamacina, a new subtribe of the tribe Naupactini (Coleoptera: Curculionidae: Entiminae) in Dominican amber, Palaeontol. Electron., 16.3.24A, 1-9, 2013.

Schlee, D.: Das Bernstein-Kabinett, Begleitheft Bernsteinausstellung Museum Löwentor, Stuttgart, 28, 1-100, 1990.

Scudder, S. H.: Tertiary Rhynchophorus Coleoptera of the United States, Mon. U.S. Geol. Survey, 21, 1-206, 1893.

Wibmer, G. J. and O'Brien, C. W.: Annotated checklist of the weevils (Curculionidae sensu lato) of South America (Coleoptera: Curculionoidea), Mem. Amer. Entomol. Inst., 39, 1-563, 1986.

Wickham, H. F.: On some fossil Rhynchophorus Coleoptera from Florissant Colorado, Bull. Amer. Mus. Nat. History, 31, 41-55, I-IV, 1912a.
Wickham, H. F.: A report on some recent of fossil Coleoptera from the Miocene Shales of Florissant, Bull. Lab. Nat. History State Univ. Iowa, 6, 3-38, I-VIII, 1912b.

Wickham, H. F.: The Princeton collection of fossil beetles from Florisant, Ann. Entomol. Soc. America, 6, 359-366, I-IV, 1913.

Wickham, H. F.: New fossil Coleoptera from the Florissant beds, Bull. Lab. Nat. History Iowa, 7, 3-19, I-IV, 1916.

Wickham, H. F.: New species of fossil beetles from Florissant, Colorado, Proc. U.S. Nat. Mus., 52, 463-472, 1917.

Zherikhin, V. V. and Gratshev, V. G.: A comparative study of the hind wing venation of the superfamily Curculionoidea, with phylogenetic implications, 633-777, in: Biology, phylogeny, and classifi cation of Coleoptera: papers celebrating the 80th birthday of Roy A. Crowson, edited by: Pakaluk, J. and Slipinski, S. A., Muzeum i Instytut Zoologii PAN, Warszawa, 1995. 